\title{
PENGEMBANGAN POTENSI KEWIRAUSAHAAN MAHASISWA FAKULTAS ILMU KOMPUTER UNIVERSITAS BUNG KARNO
}

\author{
Mega Tri Kurnia, Syamsu Marlin, Erita Oktasari dan Salomon Babys \\ Universitas Bung Karno \\ E-mail: mega_trikurnia@ubk.ac.id
}

\begin{abstract}
ABSTRAK. Fakultas Ilmu Komputer Universitas Bung Karno (FIKOM UBK) merupakan salah satu dari lima fakultas yang ada di Universitas Bung Karno. Jumlah mahasiswa aktif FIKOM UBK per tahun 2018 adalah 914 orang, dari 914 mahasiswa tersebut terdapat hanya 53 mahasiswa yang mulai merintis kewirausahaan. Kecilnya jumlah mahasiswa dan alumni FIKOM UBK yang merintis dan terlibat kewirausahaan disebabkan oleh beberapa hal, salah satunya adalah sistem pembelajaran yang diterapkan masih terfokus mempersiapkan mahasiswa untuk lulus tepat waktu dan mendapatkan pekerjaan, bukan lulusan yang siap menciptakan pekerjaan (job seekers). Solusi Tim pengabdi Program Pengembangan Potensi Kewirausahaan (PPK) untuk terhadap masalah ini adalah adalah menawarkan model pengajaran dan pelatihan kewirausahaan kepada mahasiswa FIKOM UBK melalui Pengembangan Potensi Kewirausahaan FIKOM UBK (PPK FIKOM UBK). Metode pendekatan PPK FIKOM UBK yang digunakan adalah Metode Pendekatan Participatory Action Learning System (PALS). metode PALS menitik beratkan peranan peserta secara aktif dalam proses pembelajaran sehingga terbentuk sistem pembelajaran yang partisipatif, metode ini terdiri dari tiga fase, yakni (1) fase penyadaran kewirausahaan (awareness), (2) fase pengkapasitasan dan pendampingan kewirausahaan (entrepreneurship capacity building), dan (3) fase pelembagaan (institutionalization). Hasil dari kegiatan PPK FIKOM UBK adalah berhasil mengembangkan potensi kewirausahaan mahasiswa dengan bukti berdirinya enam wirausaha baru yang kreatif dan inovatif serta tingginya minat dan motivasi mahasiswa untuk berwirausaha.
\end{abstract}

Kata kunci: Pengembangan; Potensi; Kewirausahaan; Mahasiswa, UBK

\begin{abstract}
The Faculty of Computer Science, Bung Karno University (FIKOM UBK) is one of the five faculties at Bung Karno University. The number of active students of FIKOM UBK per year 2018 is 914 people, of the 914 students there are only 53 students who have started entrepreneurship. The small number of students and alumni of FIKOM UBK who pioneered and were involved in entrepreneurship was caused by several things, one of which was that the learning system applied was still focused on preparing students to graduate on time and get a job, not graduates who were ready to create jobs (job seekers). The solution of the Entrepreneurship Potential Development Program (PPK) service team for this problem is to offer a teaching model and entrepreneurship training to FIKOM UBK students through the Development of the Entrepreneurship Potential of FIKOM UBK (PPK FIKOM UBK). The PPK FIKOM UBK approach method used is the Participatory Action Learning System (PALS) approach. The PALS method emphasizes the role of participants actively in the learning process so that a participatory learning system is formed, this method consists of three phases, namely (1) the entrepreneurial awareness phase, (2) the entrepreneurship capacity building phase, and (3) the institutionalization phase. The results of the PPK FIKOM UBK activities are the success in developing the entrepreneurial potential of students with evidence of the establishment of six new creative and innovative entrepreneurs and the high interest and motivation of students to become entrepreneurs.
\end{abstract}

\section{PENDAHULUAN}

Kewirausahaan merupakan suatu hal penting dalam pembangunan ekonomi. Perekonomian Indonesia semakin naik dan berkembang melalui aktivitas-aktivitas kewirausahaan yang dilakukan oleh perorangan maupun kelompok usaha. Oleh karena itu, untuk mengurangi tingkat pengangguran diperlukan gerakan-gerakan kewirausahaan sebagai salah satu langkah yang bisa dilakukan untuk mempengaruhi pola pikir Masyarakat Indonesia yang selama ini hanya berpikir untuk mendapatkan pekerjaan setelah lulus sekolah/kuliah.

Perguruan tinggi merupakan satu mediator dan fasilitator terdepan dalam membangun generasi muda bangsa menjadi generasi cerdas yang mandiri, kreatif, inovatif dan mampu menciptakan berbagai peluang usaha atau lapangan pekerjaan. Salah satu usaha perguruan tinggi dalam membangun generasi bangsa adalah menyelenggaraka pendidikan dan pelatihan kewirausahaan yang merupakan proses penting untuk menumbuhkan jiwa kewirausahaan kepada mahasiswa agar tercipta semangat inovasi dan kreativitas dalam diri mahasiswa.

Fakultas Ilmu Komputer Universitas Bung Karno (FIKOM UBK) merupakan salah satu dari lima fakultas yang ada di Universitas Bung Karno yang terletak di Jalan Kimia, No.20, Menteng, Jakarta Pusat. FIKOM UBK memiliki dua Program Studi (Prodi) yaitu Prodi Sistem Komputer dan Prodi Sistem Informasi. Jumlah mahasiswa aktif FIKOM UBK per tahun 2018 adalah 914 orang, dari 914 mahasiswa tersebut terdapat 53 mahasiswa yang mulai merintis kewirausahaan yang terdiri dari 24 orang peserta program Kompetisi Bisnis Mahasiswa Indonesia (KBMI) periode 2018 dan 29 orang mahasiswa yang membuka usaha secara mandiri. 
Berdasarkan hasil tracer studi alumni FIKOM UBK pada tahun 2016, menunjukkan bahwa dari 712 alumni yang mengisi dan mengumpulkan kuesioner tracer studi diperoleh informasi dengan rincian: $55,6 \%$ atau 393 alumni bekerja sesuai bidang keilmuan akademik; 34,7\% atau 247 alumni bekerja tidak sesuai bidang keilmuan; 2,6\% atau 19 alumni bekerja dengan wirausaha sendiri; $0,8 \%$ atau 6 alumni melanjutkan studi S2; dan 6,6\% atau 47 alumni belum bekerja atau menjadi ibu rumah tangga.

Kecilnya jumlah mahasiswa dan alumni FIKOM UBK yang merintis dan terlibat kewirausahaan disebabkan oleh beberapa hal berikut:

1. Sistem pembelajaran yang diterapkan di FIKOM UBK saat ini masih terfokus mempersiapkan mahasiswa untuk lulus tepat waktu dan mendapatkan pekerjaan, bukan lulusan yang siap menciptakan pekerjaan (job seekers).

2. Pembinaan potensi mahasiswa selama menempuh studi di FIKOM UBK lebih dominan mengembangkan aspek kognitif dan peningkatan skill mahasiswa pada bidang ilmu komputer.

3. Penyelanggaraan pelatihan kewirausahan masih bersifat insidental dan tidak terjadwal yang dilaksanakan ketika ada kompetisi kewirausahaan mahasiswa.

4. Belum ada wadah atau unit kewirausahaan di FIKOM UBK untuk menyalurkan bakat dan minat berwirausaha mahasiswa;

Berdasarkan permasalahan di atas, maka Tim PPK FIKOM UBK melaksanakan Program Pengembangan Kewirausahaan untuk mengatasi masalah tersebut dengan judul: Pengembangan Potensi Kewirausahaan Mahasiswa Fakultas Ilmu Komputer Universitas Bung Karno.

\section{METODE}

Pelaksanaan Program Pengembangan Kewirausahaan Fakultas Ilmu Komputer Universitas Bung Karno (PPK FIKOM UBK) dilaksanakan pada bulan Maret 2019 sampai dengan bulan September 2019 di Universitas Bung Karno.

Metode pendekatan PPK FIKOM UBK yang digunakan adalah Metode Pendekatan Participatory Action Learning System (PALS). metode PALS menitik beratkan peranan peserta secara aktif dalam proses pembelajaran sehingga terbentuk sistem pembelajaran yang partisipatif, metode ini terdiri dari tiga fase, yakni (1) fase penyadaran kewirausahaan (awareness), (2) fase pengkapasitasan dan pendampingan kewirausahaan (entrepreneurship capacity building), dan (3) fase pelembagaan (institutionalization). Fase lebih lengkap ditunjukkan pada gambar di bawah ini

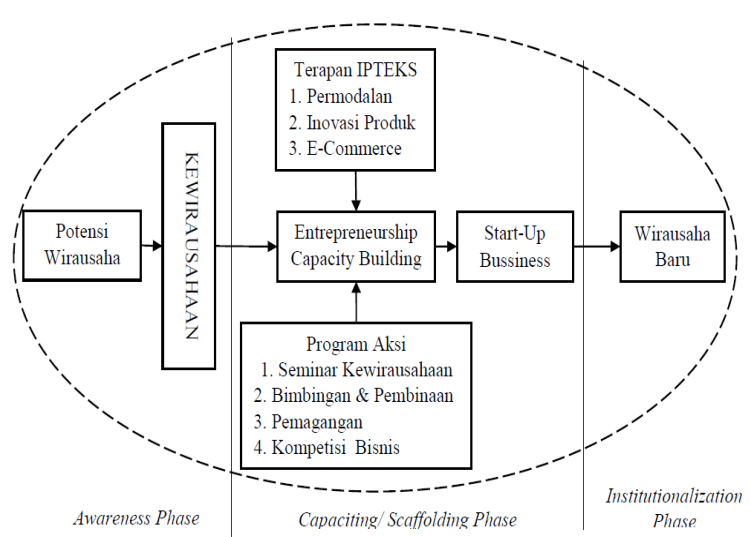

Gambar 1. Metode pendekatan Participatory Action Learning System (PALS)

Fase penyadaran kewirausahaan (Awareness) adalah tahapan memotivasi dan mengajak mahasiswa Universitas Bung Karno untuk berwirausaha, fase ini dilakukan melalui sosialisasi dan rekruitmen Tenant Kewirausahaan FIKOM UBK.

Fase pengkapasitasan dan pendampingan kewirausahaan (Entrepreneurship Capacity Building) merupakan tahapan pengembangan potensi kewirausahaan Tenant Kewirausahaan FIKOM UBK yang dilakukan melalui: (1) Seminar Kewirausahaan, (2) Pembinaan Tenant PPK FIKOM UBK, (3) Pengembangan usaha tenant melalui tambahan modal usaha, (4) Pemagangan tenant di dunia usaha, (5) Evaluasi Implementasi Kewirausahaan Tenant, (6) Entrepreneurship Award.

Fase pelembagaan (Institutionalization) merupakan tahapan penguatan usaha Tenant PPK FIKOM UBK melalui legalitas usaha dan kolaborasi usaha tenant.

\section{HASIL DAN PEMBAHASAN}

Tim PPK FIKOM Universitas Bung Karno melaksanakan kegiatan PPK pertama pada hari Sabtu, 30 Maret 2019 berupa Seminar Kewirausahaan dengan judul Seminar dan Pelatihan Kewirausahaan Mahasiswa Universitas Bung Karno yang bertempat di Aula Dr. Ir. Soekarno. Acara Seminar dan Pelatihan Kewirausahaan ini dihadiri 180 peserta dengan pembicara William Darius, SE, MM (CEO Master Lada) dan Mega Tri Kurnia, S.Pd.I, M.Si selaku Ketua Tim Pengembangan Potensi Kewirausahaan FIKOM UBK.

Acara Seminar dan Pelatihan Kewirausahaan ini bertujuan untuk melatih para mahasiswa menjadi wirausaha muda dan mampu mengembangkan usaha yang telah mereka jalani. Hasil dari Seminar dan Pelatihan Kewirausahaan ini adalah banyak peserta yang berminat merintis usaha baru dan ingin bergabung menjadi Tenant PPK FIKOM UBK.

Kegiatan kedua yang dilaksanakan oleh Tim PPK FIKOM UBK adalah memberikan arahan dan binaan dalam bentuk bimbingan tatap muka secara 
individual kepada Tenant PPK FIKOM UBK untuk menentukan jenis usaha yang akan mereka rintis dan kembangkan sesuai dengan minat dan potensi mereka.

Salah satu upaya yang dilakukan Tim PPK FIKOM UBK untuk mendapatkan modal usaha tambahan bagi tenant adalah membimbing Tenant untuk mengikuti seleksi tambahan modal usaha KEMENPORA. Pada tahapan ini ada lima Tenant PPK FIKOM UBK yang memperoleh tambahan modal usaha dari KEMENPORA. Tim PPK juga memberikan Tambahan Modal Usaha berupa alat atau bahan produksi seharga 3-4 juta rupiah kepada enam tenant yang terpilih dalam seleksi.

Fase pengkapasitasan dan pendampingan kewirausahaan Tenant PPK FIKOM UBK menghasilkan enam wirausaha baru, yaitu: dua tenant industri kreatif, dua tenant industri jasa perdagangan dan dua tenant industri makanan dan minuman.

Berdasarkan Metode Pendekatan Participatory Action Learning System (PALS) diketahui bahwa Program Pengembangan Kewirausahaan Fakultas Ilmu Komputer Universitas Bung Karno (PPK FIKOM UBK) berhasil mengembangkan potensi kewirausahaan mahasiswa UBK dengan bukti berdirinya enam wirausaha baru yang kreatif dan inovatif serta tingginya minat dan motivasi mahasiswa untuk berwirausaha.

\section{SIMPULAN}

Program Pengembangan Kewirausahaan Fakultas Ilmu Komputer Universitas Bung Karno (PPK FIKOM UBK) berhasil mengembangkan potensi kewirausahaan mahasiswa UBK dengan bukti berdirinya enam wirausaha baru yang kreatif dan inovatif serta tingginya minat dan motivasi mahasiswa untuk berwirausaha

\section{UCAPAN TERIMAKASIH}

Kami Tim PPK FIKOM UBK mengucapkan terima kasih yang sebesar-besarnya kepada DRPM Ristekdikti yang sudah mendanai program PPK ini dan terima kasih juga kami haturkan kepada Civitas Akademika Universitas Bung Karno yang sudah membantu dan mendukung kami sehingga program pengabdian PPK bisa berjalan dengan sangat baik

\section{DAFTAR PUSTAKA}

BPS, "Februari 2018: Tingkat Pengangguran Terbuka (TPT) sebesar 5,13 persen, Rata-rata upah buruh per bulan sebesar 2,65 juta rupiah", https://www.bps.go.id/ pressrelease/2018/05/07/1484/februari-2018, diakses pada 01 Agutus 2018.

Direktorat Jenderal Penguatan Inovasi. 2017. Panduan Program Calon Perusahaan Pemula Berbasis Teknologi Dari Perguruan Tinggi (Calon Startup). Jakarta: Kementerian Riset Teknologi dan Pendidikan Tinggi. 2018.

Sulistiyowati, W., Agustini, I., \& Fitriyah, H. Peningkatan Kapasitas Entrepreneurship melalui Pelatihan dan Magang Bagi Tenant di Universitas Muhammadiyah Sidoarjo. Jurnal Pengabdian pada Masyarakat. Vol. 1, No. 1, $1-5,2016$

Suranto, Muhtadi, D.P. Kuswaji, dan B.S. Totok, "Pengembangan Inkubator Kewirausahaan di Universitas Muhammadiyah Surakarta," WARTA, vol .19, no.1, pp.01 - 09, ISSN 1410-9344, Maret 2016. 